\title{
Experimental Study on Mechanical Properties of High Strength Glass Fiber Reinforced Light Weight Aggregate Concrete
}

\author{
Yarramsetty Aditya ${ }^{1} \mid$ J. Lakshmi Sudha ${ }^{2} \mid$ Dr. Dumpa Venkateswarlu ${ }^{3}$ \\ ${ }^{1}$ PG Scholar, Department of Civil Engineering, Godavari Institute of Engineering \& Technology (A), Rajahmundry. \\ ${ }^{2}$ Assistant Professor, Department of Civil Engineering, Godavari Institute of Engineering \& Technology (A), Rajahmundry. \\ ${ }^{3}$ Professor \& Head, Department of Civil Engineering, Godavari Institute of Engineering \& Technology (A), Rajahmundry.
}

To Cite this Article

Yarramsetty Aditya., J. Lakshmi Sudha \& Dr. Dumpa Venkateswarlu. International Journal for Modern Trends in Science and Technology 7, 28-38 (2021).

\section{Article Info}

Received on 06-April-2021, Revised on 26-April-2021, Accepted on 30-April-2021, Published on 03-May-2021.

\section{ABSTRACT}

Over the past few decades, extensive studies were in progress all around the globe in concrete technology in finding sustainable alternative materials that can partially or fully replace OPC along with the requirements like durability and strength aspects. Among all the available alternative materials, the industrial waste exhausts like fly ash, silica fume, GGBS, metakaoline and rice husk ash etc., are found to be quite promising. In the present study, a mix design high strength grade concrete of $M 60$ is produced by using binary blending technique by the utilization of Silica fume(SF) and Metakaoline(MK) as partial replacement by weight of cement at different blended percentages ranging from $0-30 \%$ in the increments of $10 \%$ along with glass fibers having aspect ratio of 100. The different proportions of glass fibers are added in the volume fraction percentages of $0.5-2 \%$ in the increments of $0.5 \%$. The test results of fiber reinforced specimens with different percentages of binary blend are compared with control specimens to study the behavior of FRC properties with various percentages of the blends as partial replacement by weight of cement. The test results concluded that the optimum blended percentage of silica fume and metakaoline is 15\% i.e., $7.5 \% \mathrm{SF}+7.5 \% \mathrm{MK}$ along with SP percentage as $1.5 \%$ and glass fiber percentage as $1.5 \%$ when compared with the control mix. Further, light weight aggregate i.e., pumice stone is replaced to this mix to coarse aggregate at percentages of 25\%,50\%,75\% and 100\% respectively and the compressive strength characteristic along with density of concrete was studied and reported.

KEYWORDS: Mechanical Properties, Glass Fibers, Volume Fraction, Blending, Light Weight Aggregate

\section{INTRODUCTION}

HSC is referred to be as High strength concrete and is basically utilized for concrete which has a compressive strength more than $41 \mathrm{MPa}$. The committee of ACI has given a definition of HSC that it is a type of concrete which has the capacity to acquire a compressive strength of design with a minimum of $41 \mathrm{MPa}$ or greater. With the design of high strength grade cement and feasibility with various types of mineral and chemical admixtures, the researchers are able to produce the concrete with more than $100 \mathrm{MPa}$ strength. The design and development of HSC has enabled the construction industry to construct taller and longer spanned structures. It is a proven fact that the relative higher compressive strength of HSC is an attractive benefit to the construction of various engineering structures. Further, the enhanced strength 
characteristic of high strength concrete leads to a problem of increase in brittle nature of the concrete. In order to reduce the aspect of brittleness, a strategy is adopted in order to inculcate the fibers within the HSC, that results in the development of a new and sustainable material with promising split-tensile strength and greater stiffness which limits the crack initiation and crack propagation.

The basic and fundamental problem with the plain concrete as well as the high strength concrete is its limited split-tensile strength as well the limited ductility with lower resistance to cracking and low split-tensile strength is due to the initiation and extension of micro cracking.

Normally, in PCC, the micro cracks propogates even before the loading time since there are two important factors such as drying shrinkage or because of the volume change. The crack dimension changes from microns to $\mathrm{mm}$. Whenever the elements of concrete are loaded, these micro cracks open up and further additional cracks will be developed in the areas where the strength of the concrete falls under deficiency due to different sequences. The micro cracking propagation is the basic and fundamental reason for the elastic deformation within the concrete structures. The inclusion of small and uniformly dispersed fibers within the concrete acts as a crack arrester which enhances the static and dynamic properties of concrete and that type of concrete is termed to be as fiber reinforced concrete.

\section{History of Utilization of Fibers in Concrete}

During the early ages, the utilization of fibers in concrete as reinforcement is in practice. In the starting stages, the hair of horse was utilized in mortar and in mud bricks, straw was utilized. In 1900's the fibers which are made up with asbestos sheets were extensively utilized in concrete. Due to the health risks that are associated with the utilization of asbestos in concrete, glass and glass and polypropylene fibers were came into existence and are being extensively utilized for various purposes these days also.

The early age studies which were performed by Ramualdi, Mandel and Batson during the times of 1950's and 60's focused on glass fiber concrete(S.F.R.C). Straight fibers were utilized at the starting stages and later different shapes of fibers were utilized because of their increased values in toughness and ductility. But the major problems that were encountered with these materials is with workability. In order to mitigate and overcome such aspect, the utilization of high range water reducers were imparted in concrete and with these advancements, today glass fibers plays a significant role in the construction industry. Further, synthetic fibers attracted the interest of researchers over the last two decades. Glass and polypropylene fibers were utilized as a secondary reinforcement to concrete in the early 90's for the construction of blast resistant buildings by the U.S.Corps.

\section{Objectives of the Study}

a. To design hybrid fiber reinforced high strength concrete by using optimized content of hybrid fibers and multi-mineral admixtures.

b. To study the mechanical strength characteristics of HSC [M60] hybrid fiber reinforced high strength light weight aggregate concrete.

\section{LITERATURE SURVEY}

P. Muthupriya et al. (2011)[1] conducted a study on the behaviour of short columns casted with HPC, i.e. high-performance concrete, and in their study, M60 grade was selected with general concrete ingredients and mineral admixtuers used in silica and fly ash at different replacement levels in cement and SP dosage was confined to 1.5 percent by weight of cement. The subsequent $\mathrm{w} / \mathrm{c}$ ratio is 0.3. Using cube, cylinder, and prism specimens, the mechanical strength characteristics were determined. The total number of casted specimens was seven, and they were assigned the numbers M1 through M7.

B.B. Patil and P.D.Kumbhar (2012) [2] investigated the strength and durability of HPC by including high reactivity metakoaline in their research. M60 grade HPC was cast with general concrete ingredients, as well as mineral admixture to replace the cement with metakaoline at various replacement levels, as well as chemical admixture 0.73 percent by weight of the cement, in their study. The $\mathrm{W} / \mathrm{B}$ ratio is currently 0.31 . In order to study the compressive strength of concrete at 28 days, a total of 6 mixes were prepared and standard cube specimens were cast by replacing the cement content with metakaoline at replacement levels of 0 percent, $5 \%, 7.5$ percent, $10 \%, 12.5 \%$, and $15 \%$. The test results revealed that the strength and durability characteristics of concrete improve when metakoline is replaced at a rate of 7.5 percent. The effect of hybrid fibres on the strength characteristics of high strength concrete was investigated by A.Ravichandran et al., [2009] 
[3]. M60 grade concrete was made using fibre hybridization, which is a combination of glass and polyoefin fibres at different volume fractions ranging from $0.5-2$ percent with a 0.5 percent increase. The mechanical strength characteristics of these mixes were identified and compared to those of the control mix.

S.Eswari et al. (2008)[4] studied HFRC performance aspects. Hybrid fiber-concrete ductility performance was studied and reported in their study. Some parameters such as the effect of fibre volume fraction, rupture modulus, ultimate, service loads and their corresponding deflections as well as the crack width, deflection and energy ductility were studied and reported. In concrete specimens ranging from $0-2$ percent with an interval of 0.5 percent, the fibres were incorporated and the ductility performance aspect was studied and compared with that of plain concrete. The test results indicated that adding $2 \%$ volume fraction of fibres to concrete significantly increased the ductility performance of high strength concrete.

A.K.Jain (2016)[5] examined the impact of glass and glass fibres on concrete strength properties, and this study continues to study H.F.R.C strength characteristics. Two fibres, glass and glass fibres, were used in the study and the objective of this study is to investigate the strength characteristics of M20 concrete with a range of $0.2-0.35 \%$ of glass and $0.4-0.55 \%$ of glass fibres by concrete volume. From the test results, mixes containing hybrid fibres show superior properties than controlled concrete.

Pajak et al. (2012)[6] investigated the flexural characteristics of S.C.C. reinforced with glass fibres at an interval of 0.5-1.5 percent compared to normal vibrated concrete NVC. Specimen testing is done according to RILEM TC 162-TDF compliance requirements. SCC's flexural characteristic is related to NVC, where the increase in fibre volume ratio causes SCC's pre- and post-crack parameters to increase. Using fibres, concrete's flexural strength increased substantially.

Sravana et al.(2010)[7] investigated the impact of glass fibres on S.C.C slabs. For this study, concrete grades M30 and M40 were chosen and the test results reported that the presence of glass fibres did not significantly affect or improve any value of flexural strength, but the development of multiple micro and macro cracks was prevented by using glass fibres in both grades of structural concrete.

Yogesh Iyer Murthy et al., (2014)[8] studied glass fibre concrete properties. For the preparation of M30-grade concrete, $22 \mathrm{~mm}$ in dia and $5 \mathrm{~cm}$ long fibres replaced the fine aggregate with 1.5 percent fibres.

Rama Mohan Rao et el (2010)[10] studied the impact of different volume fractions of glass fibres on the mechanical strength properties of concrete using $25 \%$ and $40 \%$ fly ash replacement to cement.

S. R. Rabadiya (2015)[12] conducted a concrete study made from glass fibre and recycled coarse aggregate as a partial substitute for coarse aggregate. They studied both the fresh and hardened properties. The recycled coarse aggregate was replaced at 10-60 percent intervals.

Ajay N. Burile et al. (2013)[15] studied and reported strength characteristics of glass and concrete fibre composites. In their study, glass fibres with different volume fractions ranging from 0.5.1 percent were added along with alkali-resistant glass fibres with 0.25 percent volume fraction and mechanical strength characteristics were compared with conventional M20 grade concrete. The test results reported a fibre impact on concrete's mechanical strength characteristics.

Mohd Khawaja Hussain et al (2015)[16] conducted a study on concrete strength aspects with partial replacement of cement with flay ash and also glass and coconut fibre. The concrete grade chosen in their study was M20 with 0.45 $\mathrm{W} / \mathrm{C}$ ratio with $1: 1.53: 2.7$ proprtion mix to determine the mechanical strength characteristics of the proposed concrete grade. Fly ash was replaced by $10-30$ percent with 10 percent interval. Furthermore, glass and coconut fibres were added in percentages ranging from $1-2 \%$ to $1 \%$. Compared with the control concrete mix, the study concluded that the optimal dosage of fly ash, glass and coconut fibres in concrete is $20 \%, 2 \%$ and $1 \%$ respectively. Also, glass fibres were better than coconut fibre.

\section{OBJECT AND SCOPE OF EXPERIMENTAL INVESTIGATION}

\section{A. EXPERIMENTAL INVESTIGATION}

The experimental study includes casting and testing of 15 sets and the size of each set comprises of 3 specimens i.e., cubes, cylinders and prisms in order to identify the mechanical strength characteristics of high strength grade concrete. Glass fibers with various volume fractions with the increments of $0.5 \%$ in the range of $0.5-2 \%$ were utilized in the present study along with different percentages of mineral admixtures like silica fume and metakaoline. The study was divided into 2 
phases and in the first phase, it is targeted to develop the HSC using mineral admixtures and in the second phase, it is aimed to decrease the brittleness of HSC using glass fibers. Standard cube, cylinder and prism specimens were casted in the present study.

\section{B. CEMENT}

Cement (OPC) is a binding substance which have adhesion and cohesion properties. This aspect furnishes the binding capability, thus act as a sustainable consturction material. OPC was classified into 3 types of grades on par with 28 day compressive strength as per the requirements of IS 4031-1988.The grades are 33 Grade, 43 Grade, 53 Grade. The cement utilized in this study was OPC 53 Grade

Table 3.1: Physical Properties of Cement

\begin{tabular}{|c|l|l|c|}
\hline S.No & \multicolumn{1}{|c|}{ Property } & Test Result \\
\hline 1. & \multicolumn{2}{|c|}{ Specific Gravity } & 3.15 \\
\hline 2. & \multicolumn{2}{|c|}{ Normal Consistency } & $30 \%$ \\
\hline 3. & \multirow{2}{*}{ Setting Time } & Initial & \multirow{2}{*}{49 Minutes } \\
\cline { 3 - 4 } & & Final & $395 \mathrm{Minutes}$ \\
\hline 4. & Compressive Strength @ 28 days & $53 \mathrm{MPa}$ \\
\hline 5. & \multicolumn{2}{|l|}{ Specific Surface Area } & $369 \mathrm{~m}^{2} / \mathrm{Kg}$ \\
\hline
\end{tabular}

Table 3.2: Chemical Composition of Cement

\begin{tabular}{|c|c|}
\hline Chemical Content & Amount (\%) \\
\hline Calcium Oxide $(\mathrm{CaO})$ & 62.7 \\
\hline Silicon dioxide $\left(\mathrm{SiO}_{2}\right)$ & 19.8 \\
\hline Aluminum Oxide $\left(\mathrm{Al}_{2} \mathrm{O}_{3}\right)$ & 6.3 \\
\hline Iron Oxide $\left(\mathrm{Fe}_{2} \mathrm{O}_{3}\right)$ & 3.6 \\
\hline Magnesium Oxide $(\mathrm{Mg} 0)$ & 2.8 \\
\hline Sodium Oxide $\left(\mathrm{Na}_{2} \mathrm{O}\right)$ & 0.8 \\
\hline Potassium Oxide $\left(\mathrm{K}_{2} \mathrm{O}\right)$ & 1.7 \\
\hline Sulphur Trioxide $\left(\mathrm{SO}_{3}\right)$ & 2.3 \\
\hline
\end{tabular}

\section{FINE AGGREGATES}

Table 3.3: Properties of Fine Aggregate

\begin{tabular}{|c|c|c|}
\hline S.No & Property & Values \\
\hline 1. & Specific Gravity & 2.62 \\
\hline 2. & Fineness Modulus & 2.6 \\
\hline 3. & Water Absorption & $1 \%$ \\
\hline 4. & Grading of Sand & Zone - II \\
\hline
\end{tabular}

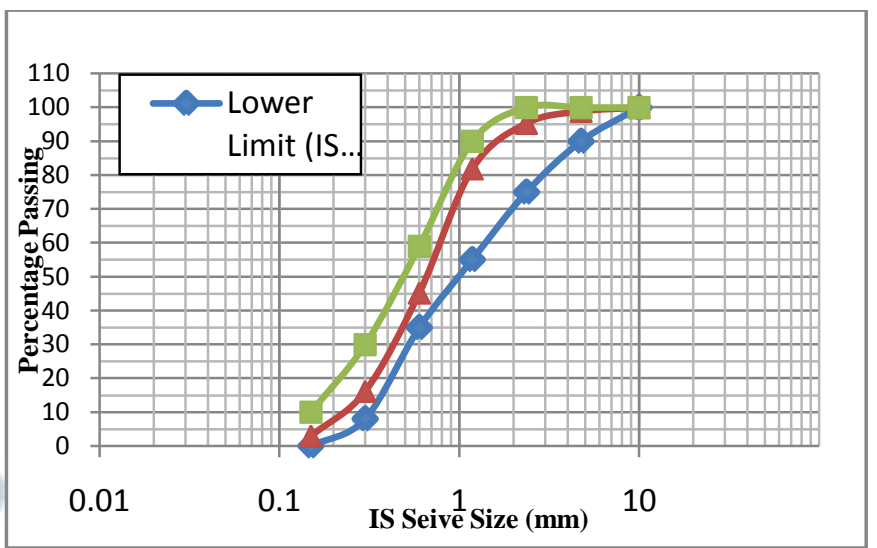

Fig: Shows The Grading curve of fine aggregate

\section{COARSE AGGREGATES}

Table 3.5: Sieve Analysis of $20 \mathrm{~mm}$ Coarse Aggregate

\begin{tabular}{|c|c|c|c|c|c|c|}
\hline & \multirow{2}{*}{ S.No } & \multirow{2}{*}{$\begin{array}{c}\text { Sieve size } \\
(\mathbf{m m})\end{array}$} & $\begin{array}{c}\text { Weight } \\
\text { retained } \\
(\mathbf{g m})\end{array}$ & $\begin{array}{c}\text { Percentage } \\
\text { weight } \\
\text { retained }\end{array}$ & $\begin{array}{c}\text { Cumulative } \\
\text { percentage } \\
\text { weight } \\
\text { retained }\end{array}$ & \multicolumn{2}{|c|}{$\begin{array}{c}\text { Cumulative percent } \\
\text { passing }\end{array}$} \\
\cline { 6 - 8 } & & $\mathbf{2 0 ~ m m}$ & $\begin{array}{c}\text { IS 383 } \\
(\mathbf{1 9 7 0}) \\
\text { Limits }\end{array}$ \\
\hline 1 & 20 & 0 & 0 & 0 & 100 & $85-100$ \\
\hline 2 & 16 & 2191.5 & 43.83 & 43.83 & 56.17 & N/A \\
\hline 3 & 12.5 & 1692.5 & 33.85 & 77.68 & 22.32 & N/A \\
\hline 4 & 10 & 853.5 & 17.07 & 94.75 & 5.29 & $0-20$ \\
\hline 5 & 4.75 & 262.5 & 5.25 & 100 & 0 & $0-5$ \\
\hline
\end{tabular}

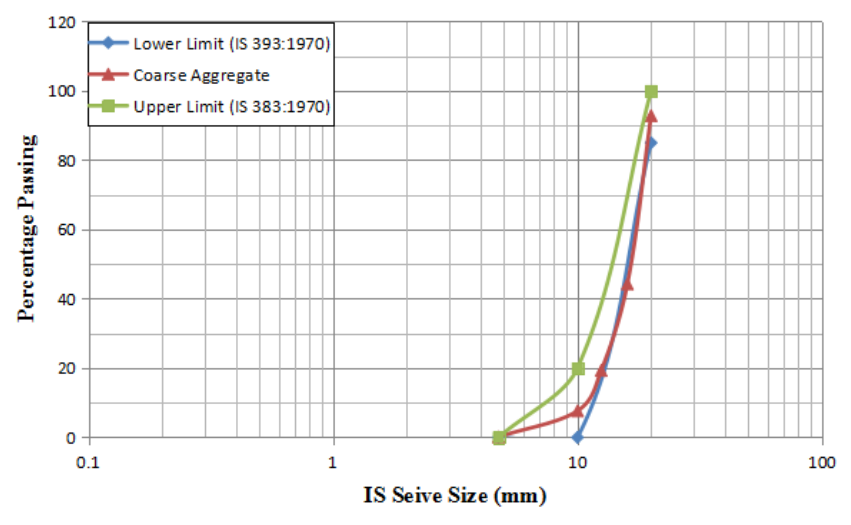

Shows The Grading curve of Coarse aggregate $20 \mathrm{~mm}$

Table 3.6: Sieve Analysis of $10 \mathrm{~mm}$ Coarse Aggregate

\begin{tabular}{|c|c|c|c|c|c|c|}
\hline & Sieve & Weight & Percentage & Cumulative & \multicolumn{2}{|c|}{ Cumulative percent passing } \\
S.No & size & $\begin{array}{c}\text { retained } \\
\text { weight }\end{array}$ & \begin{tabular}{c} 
percentage \\
weight \\
\cline { 5 - 7 }
\end{tabular} & $\begin{array}{c}\mathbf{1 0} \\
\mathbf{( m m})\end{array}$ & retained & IS 383 (1970) limits \\
retained & $\mathbf{m m}$ & \\
\hline 1 & 10 & 16 & 0.32 & 0.32 & 99.68 & $85-100$ \\
\hline 2 & 4.75 & 4546 & 90.92 & 91.24 & 8.76 & $0-20$ \\
\hline 3 & 2.36 & 318 & 6.36 & 97.6 & 2.4 & $0-5$ \\
\hline
\end{tabular}




\section{E. WATER}

As per the codal provisions, clean and potable water should be utilized in order to prepare concrete mix. The water should be free from deleterious materials like oils, fats, sugars, slats $\&$ other organic matter. In general, water which is free from impurities and which is fit for drinking is utilized in order to prepare concrete mix. Mainly, water has two functions in a concrete mix. Firstly, it gets react with cement material in order to form C-S-H gel and also forms a suspension with the inert materials in the concrete up to the hardening of cement paste takes place. Further, it acts a lubricant or a vehicle in the mixture of mortar

Table 3.10: Permissible Limits of Water As Per IS: 456-2000

\begin{tabular}{|c|c|c|c|}
\hline S.No & Impurity & Maximum limit & Result \\
\hline 1. & $\mathrm{p}^{\mathrm{H}}$ Value & 6 to 8.5 & 7 \\
\hline 2. & Suspended matter $\mathrm{mg} /$ lit & 2000 & 220 \\
\hline 3. & Organic matter $\mathrm{mg} /$ lit & 200 & 20 \\
\hline 4. & Inorganic matter $\mathrm{mg} /$ lit & 3000 & 150 \\
\hline 5. & Sulphate $\left(\mathrm{SO}_{4}\right) \mathrm{mg} /$ lit & 500 & 30 \\
\hline 6. & Chlorides $\mathrm{mg} /$ /lit & $\begin{array}{c}2000 \text { for P.C.C. } \\
1000 \text { for R.C.C }\end{array}$ & 60 \\
& & & \\
\hline
\end{tabular}

\section{METAKAOLIN}

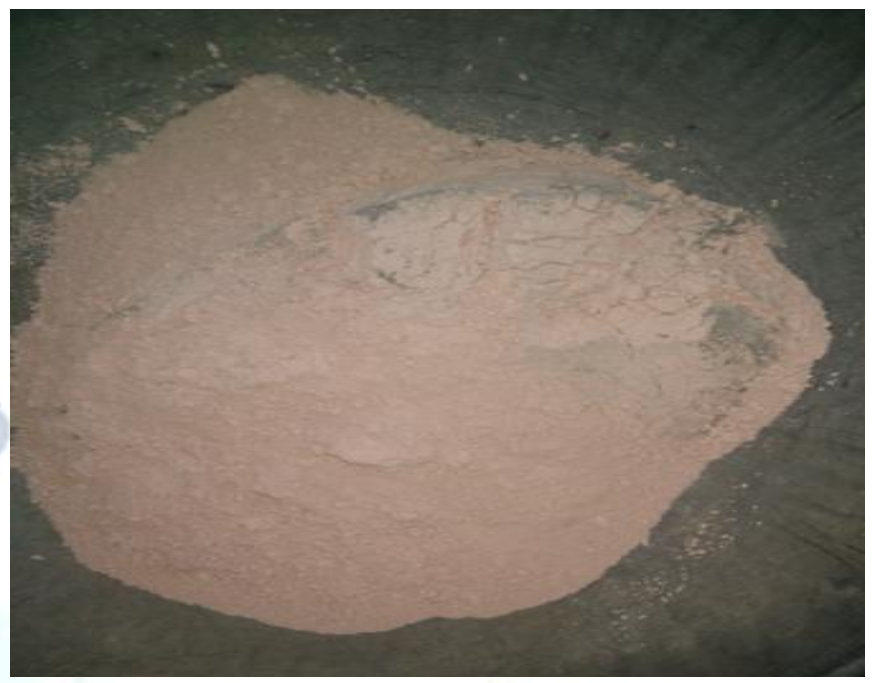

Fig: Metakaoline

\section{TEST RESULTS AND DISCUSSIONS:}

Table 6: Test Results of Mechanical Properties of High Strength Concrete with the addition of multi-mineral admixtures at 28 days

\begin{tabular}{|c|c|c|c|c|c|c|c|c|c|c|c|}
\hline \multirow[t]{2}{*}{ S.No } & \multirow[t]{2}{*}{ Mix Designation } & \multirow[t]{2}{*}{$\begin{array}{l}\text { Slump Cone } \\
\text { Results } \\
(\mathrm{mm})\end{array}$} & \multicolumn{3}{|c|}{$\begin{array}{l}\text { Compressive } \\
\text { Strength } \mathrm{MPa}\end{array}$} & \multicolumn{3}{|c|}{$\begin{array}{l}\text { Split-tensile } \\
\text { Strength } \\
\mathrm{MPa}\end{array}$} & \multicolumn{3}{|c|}{$\begin{array}{c}\text { Flexural } \\
\text { Strength } \\
\mathrm{MPa}\end{array}$} \\
\hline & & & $\begin{array}{c}07 \\
\text { days }\end{array}$ & $\begin{array}{c}14 \\
\text { days }\end{array}$ & $\begin{array}{c}28 \\
\text { days }\end{array}$ & $\begin{array}{l}07 \\
\text { days }\end{array}$ & $\begin{array}{c}14 \\
\text { days }\end{array}$ & $\begin{array}{c}28 \\
\text { days }\end{array}$ & $\begin{array}{c}07 \\
\text { days }\end{array}$ & $\begin{array}{c}14 \\
\text { days }\end{array}$ & $\begin{array}{l}28 \\
\text { days }\end{array}$ \\
\hline 1. & $\begin{array}{l}\text { M60 } \\
\text { Control Mix }\end{array}$ & 37 & 30.21 & 47.54 & 60.65 & 1.12 & 2.68 & 4.13 & 3.54 & 5.12 & 7.94 \\
\hline 2. & $\begin{array}{l}(5+5) \\
(\mathrm{SF}+\mathrm{MK}) \\
1 \% \mathrm{SP}\end{array}$ & 34 & 33.32 & 50.64 & 65.76 & 1.07 & 2.10 & 3.55 & 3.47 & 5.04 & 7.86 \\
\hline 3. & $\begin{array}{c}(5+5) \% \\
(\mathrm{SF}+\mathrm{MK}) \\
1.5 \% \mathrm{SP}\end{array}$ & 38 & 31.54 & 48.00 & 61.32 & 1.98 & 2.72 & 4.25 & 3.86 & 5.24 & 8.11 \\
\hline 4. & $\begin{array}{l}(5+10) \% \\
(\mathrm{SF}+\mathrm{MK}) \\
1 \% \mathrm{SP}\end{array}$ & 36 & 33.76 & 49.76 & 64.41 & 1.64 & 2.54 & 3.67 & 1.98 & 3.96 & 5.39 \\
\hline 5. & $\begin{array}{l}(5+10) \% \\
(\mathrm{SF}+\mathrm{MK}) \\
1.5 \% \mathrm{SP}\end{array}$ & 37 & 29.32 & 45.77 & 57.77 & 1.49 & 2.09 & 3.52 & 3.76 & 5.10 & 7.85 \\
\hline 6. & $\begin{array}{l}(10+5) \% \\
(\mathrm{SF}+\mathrm{MK}) \\
1 \% \mathrm{SP}\end{array}$ & 33 & 30.65 & 49.32 & 59.19 & 1.32 & 2.07 & 3.41 & 1.85 & 3.12 & 5.41 \\
\hline 7. & $\begin{array}{l}(10+5) \% \\
(\mathrm{SF}+\mathrm{MK}) \\
1.5 \% \mathrm{SP}\end{array}$ & 33 & 31.10 & 48.43 & 61.54 & 1.24 & 1.96 & 2.83 & 2.12 & 3.64 & 5.8 \\
\hline
\end{tabular}




\begin{tabular}{|c|c|c|c|c|c|c|c|c|c|c|c|}
\hline 8. & $\begin{array}{l}(7.5+7.5) \% \\
(\mathrm{SF}+\mathrm{MK}) \\
1 \% \mathrm{SP}\end{array}$ & 35 & 33.21 & 49.76 & 65.77 & 2.10 & 2.74 & 4.24 & 3.18 & 5.10 & 8.00 \\
\hline 9. & $\begin{array}{l}(7.5+7.5) \% \\
(\mathrm{SF}+\mathrm{MK}) \\
1.5 \% \mathrm{SP}\end{array}$ & 38 & 33.84 & 50.21 & 67.11 & 2.16 & 2.89 & 4.38 & 4.10 & 5.98 & 8.75 \\
\hline 10. & $\begin{array}{l}(10+10) \% \\
(\mathrm{SF}+\mathrm{MK}) \\
1 \% \mathrm{SP}\end{array}$ & 34 & 30.66 & 49.31 & 58.67 & 1.51 & 2.15 & 3.54 & 1.79 & 3.78 & 5.62 \\
\hline 11. & $\begin{array}{l}(10+10) \% \\
(\mathrm{SF}+\mathrm{MK}) \\
1.5 \% \mathrm{SP}\end{array}$ & 36 & 33.12 & 48.87 & 63.56 & 1.09 & 1.84 & 2.55 & 3.31 & 5.04 & 7.75 \\
\hline
\end{tabular}

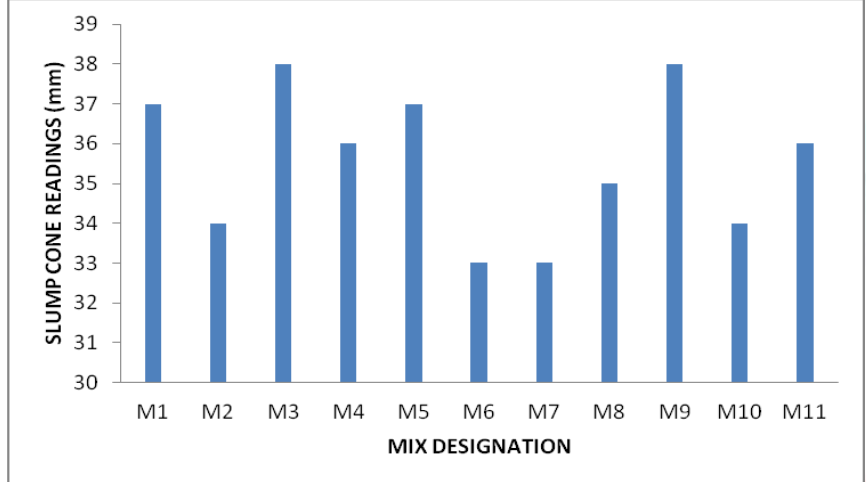

Fig: Slump Cone values of fresh concrete mix Fig. furnishes the fresh concrete property i.e., slump cone values. From the above graph, it can be concluded that with the increase in percentage replacement of mineral admixtures in the concrete mix, the workability was found to be decreased and with the increase in SP content, the workability was found to be increased.

The optimal workability percentage for the development of M60 grade high strength concrete mix was found to be $1.5 \%$.

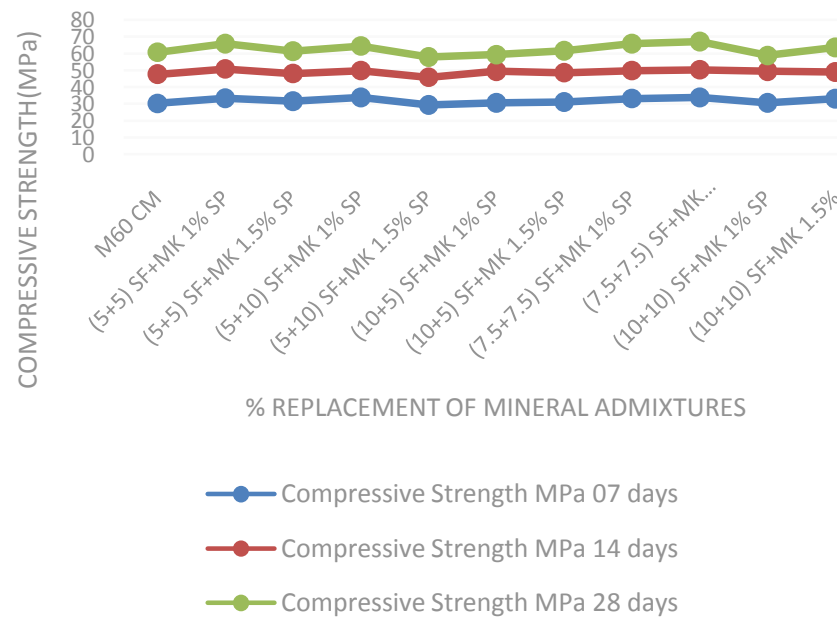

Fig. Compressive Strength of concrete at various percentage replacement of mineral admixtures after 7,14 and 28 days of curing
Fig. furnishes the compressive strength of high strength grade concrete at different percentage replacements of mineral admixtures after 7,14 and 28 days of curing. Of all the mixes, $(7.5+7.5 \%)$ $\mathrm{SF}+\mathrm{MK}$ with $1.5 \%$ SP has attained maximum compressive strength at all stages of curing and.

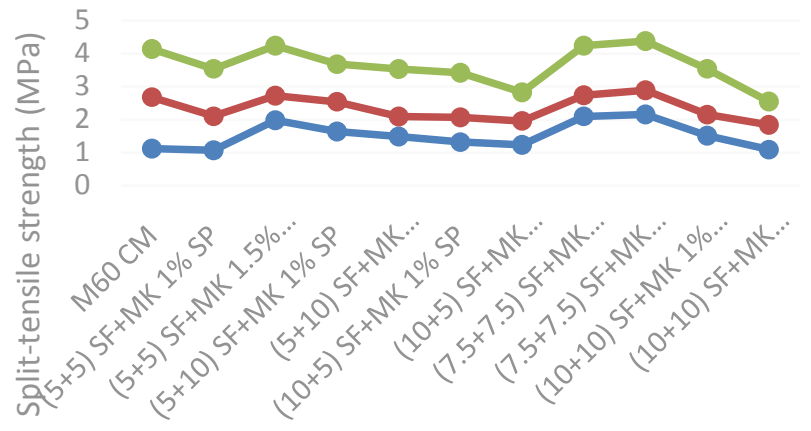

$\%$ replacement of mineral admixtures

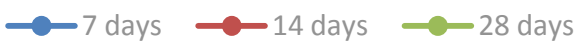

Fig. Split-split-tensile strength of concrete at various percentage replacement of mineral admixtures after 7,14 and 28 days of curing

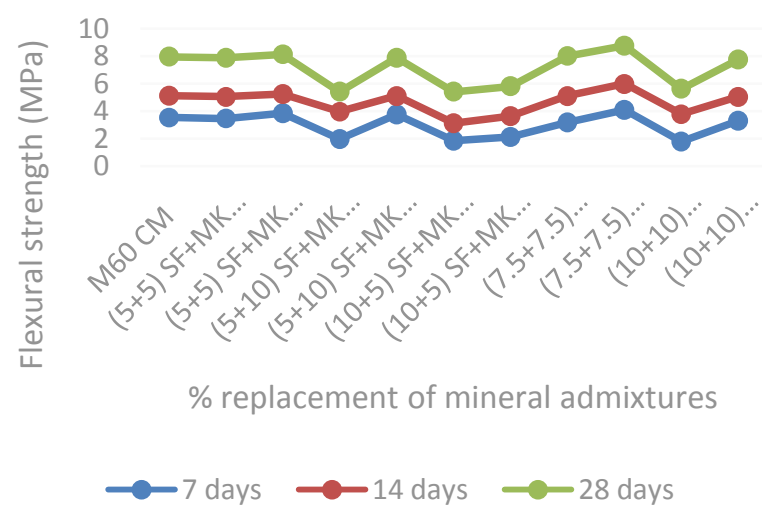

Fig. Flexural strength of concrete at various percentage replacement of mineral admixtures after 7,14 and 28 days of curing 


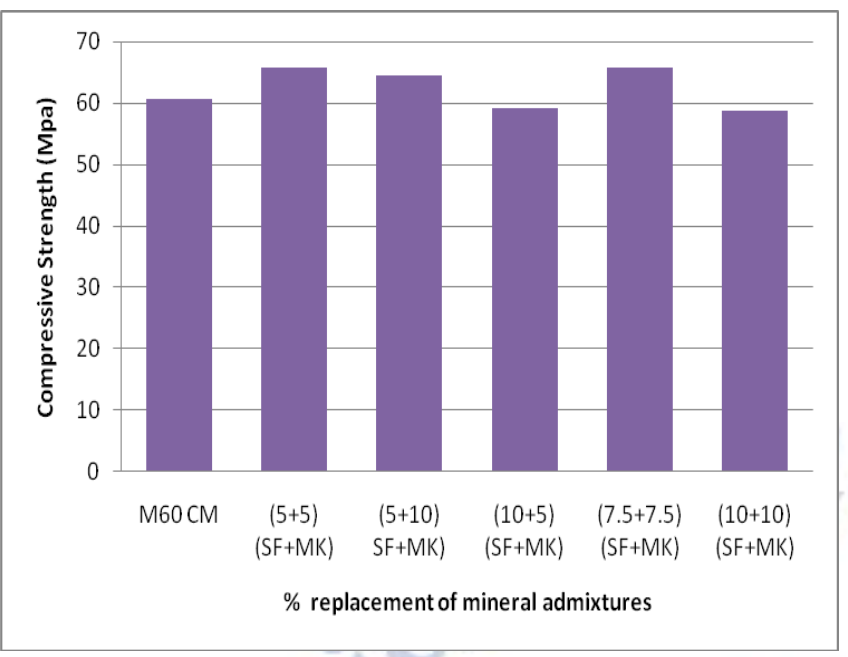

Fig: Graph showing variations in Compressive Strength of Concrete at 1\%SP after 28 days of curing

From the above graph, it is observed that the compressive strength value is higher for the trail mix $(7.5 \mathrm{SF}+7.5 \mathrm{MK})$ with $1 \% \mathrm{SP}$, found to be higher compared with other trail mixes.

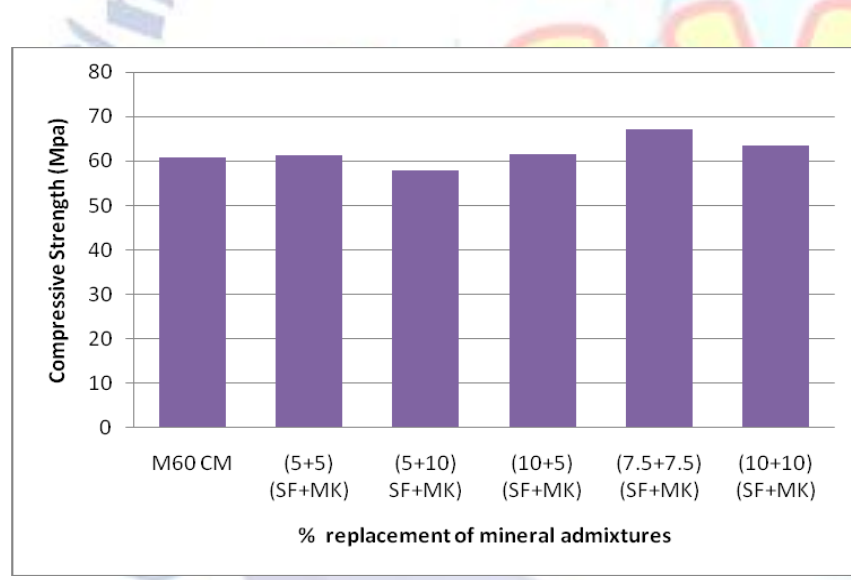

Fig: Graph showing variations in Compressive Strength of Concrete at $1.5 \%$ SP after 28 days of curing

From the above graph, it is observed that the compressive strength value is higher for the trail mix $(7.5 \mathrm{SF}+7.5 \mathrm{MK})$ with $1.5 \% \mathrm{SP}$, found to be higher compared with other trail mixes.

Hence, it is considered for further study to improve the ductility of the high strength concrete

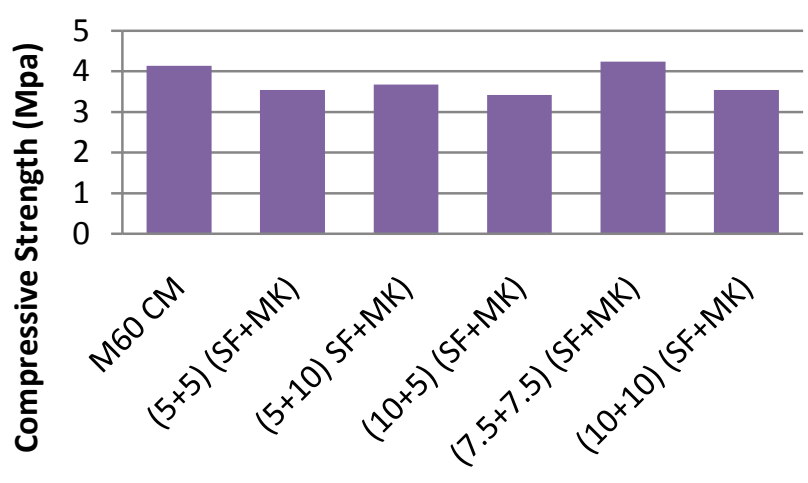

$\%$ replacement of mineral admixtures

Fig: Graph showing variations in Split-tensile Strength of concrete at $1 \%$ SP after 28 days of curing

From the above graph, it is observed that the flexural strength value is higher for the trail mix $(7.5 \mathrm{SF}+7.5 \mathrm{MK})$ with $1.5 \% \mathrm{SP}$, found to be higher compared with other trail mixes.

Table 7 : Mechanical properties of various proportions of glass fibers on M60 grade High Strength Concrete at 28 days

\begin{tabular}{|c|c|c|c|c|c|}
\hline S.No & $\begin{array}{c}\text { Mix } \\
\text { Designation }\end{array}$ & $\begin{array}{c}\text { \% of } \\
\text { Glass } \\
\text { Fibers }\end{array}$ & $\begin{array}{c}\text { Compressive } \\
\text { Strength } \\
\mathrm{MPa}\end{array}$ & $\begin{array}{c}\text { Split-tensile } \\
\text { Strength } \\
\mathrm{MPa}\end{array}$ & $\begin{array}{c}\text { Flexural } \\
\text { Strength } \\
\mathrm{MPa}\end{array}$ \\
\hline 1. & $\begin{array}{r}\mathrm{M} 60 \\
\text { Control Mix }\end{array}$ & 0 & 60.65 & 4.13 & 7.94 \\
\hline 2. & $\begin{array}{c}(7.5+7.5) \% \\
(\mathrm{SF}+\mathrm{MK}) \\
1.5 \% \mathrm{SP}\end{array}$ & 0.5 & 72.4 & 5.09 & 9.75 \\
\hline 3. & $\begin{array}{c}(7.5+7.5) \% \\
(\mathrm{SF}+\mathrm{MK}) \\
1.5 \% \mathrm{SP}\end{array}$ & 1.0 & 74.6 & 5.37 & 11.25 \\
\hline 4. & $\begin{array}{c}(7.5+7.5) \% \\
(\mathrm{SF}+\mathrm{MK}) \\
1.5 \% \mathrm{SP}\end{array}$ & 1.5 & 77.7 & 5.65 & 12.25 \\
\hline 5. & $\begin{array}{c}(7.5+7.5) \% \\
(\mathrm{SF}+\mathrm{MK}) \\
1.5 \% \mathrm{SP}\end{array}$ & 2 & 76.8 & 5.51 & 11.75 \\
\hline
\end{tabular}

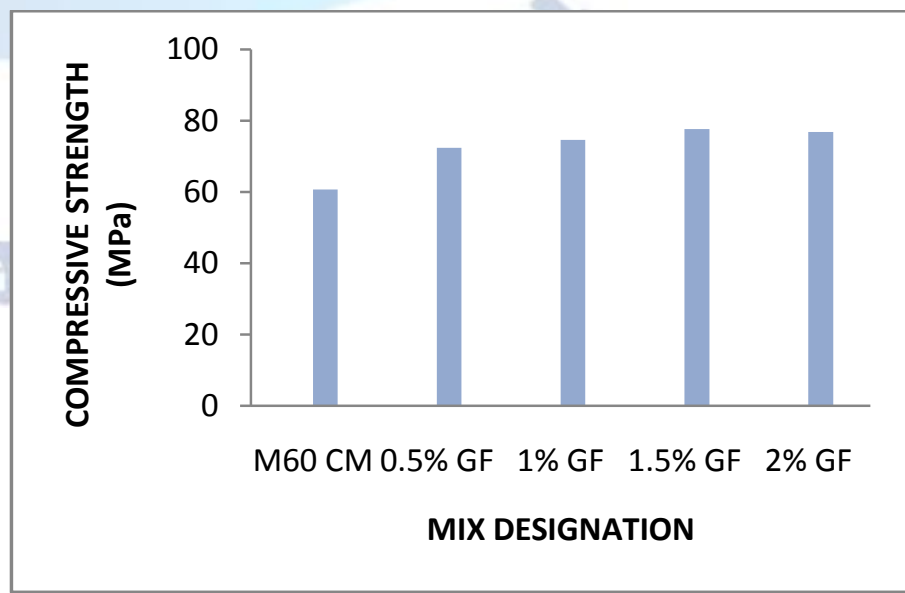

Fig:Variation of Compressive Strengths by incorporating Glass Fibers 


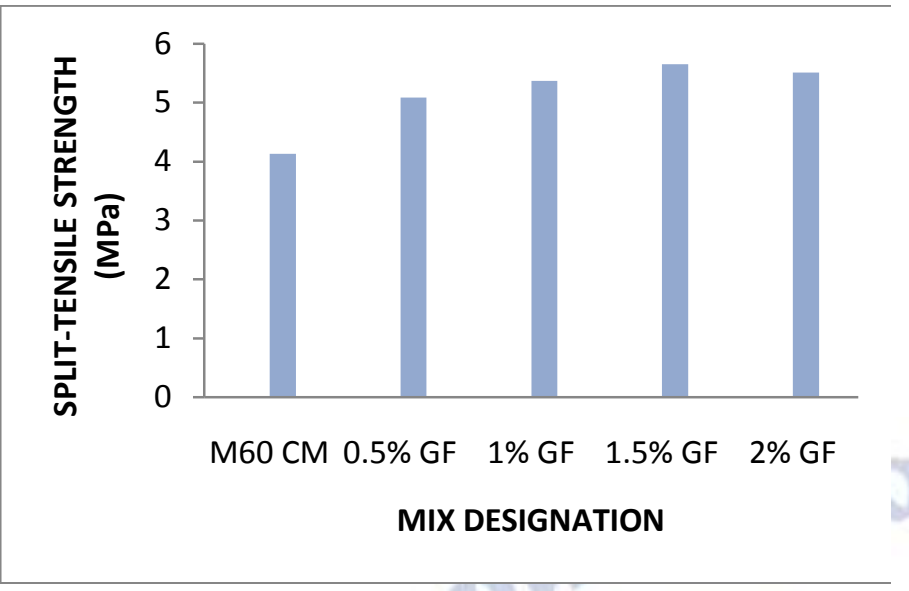

Fig:Variation of Split-tensile Strengths by incorporating Glass Fibers

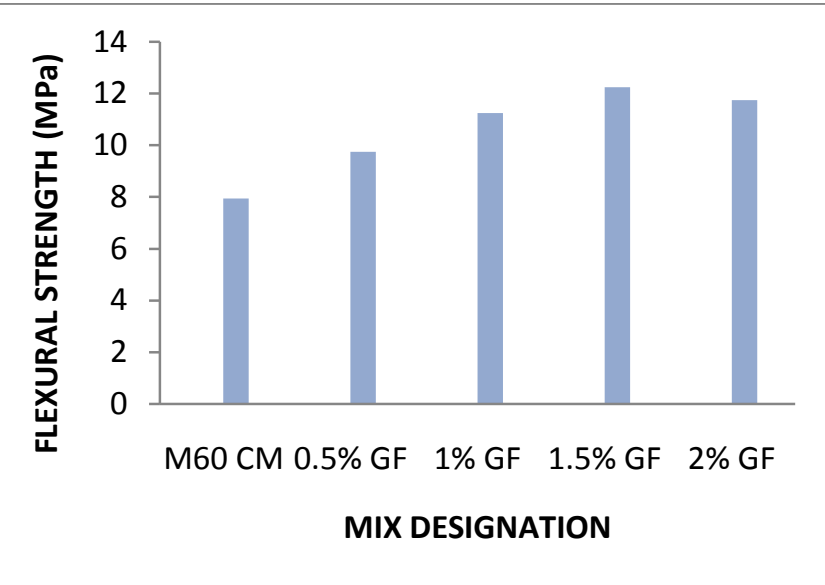

Fig:Variation of Flexural Strengths by incorporating Glass Fibers

The mix with $(7.5+7.5 \%) \mathrm{SF}+\mathrm{MK}$ with $1.5 \% \mathrm{SP}$ and $1.5 \%$ glass fibers achieved maximum mechanical strength characteristics and this mix is taken for further to reduce the density of high strength concrete by utilizing light weight aggregate i.e., pumice stone.

Table 8 : Mechanical properties various proportions of pumice stone on M60 grade High Strength glass fiber reinforced light weight Concrete at 28 days

\begin{tabular}{|c|c|c|c|c|c|c|}
\hline S.No & Mix Designation & $\begin{array}{l}\text { \% of } \\
\text { pumice } \\
\text { stone }\end{array}$ & $\begin{array}{l}\text { Weight } \\
\text { of cube } \\
\text { (Kgs) }\end{array}$ & $\begin{array}{l}\text { Compressive } \\
\text { Strength } \\
\mathrm{MPa}\end{array}$ & $\begin{array}{l}\text { split-tensile } \\
\text { Strength } \\
\mathrm{MPa}\end{array}$ & $\begin{array}{c}\text { Flexural } \\
\text { Strength } \\
\mathrm{MPa}\end{array}$ \\
\hline 5 & $\begin{array}{c}(7.5+7.5) \% \\
(\mathrm{SF}+\mathrm{MK}) \\
1.5 \% \mathrm{SP} \\
1.5 \% \mathrm{GF} \\
-\mathrm{M} 1\end{array}$ & 0 & 9.98 & 77.7 & 5.65 & 12.25 \\
\hline 2. & $\begin{array}{c}(7.5+7.5) \% \\
(\mathrm{SF}+\mathrm{MK}) \\
1.5 \% \mathrm{SP} \\
1.5 \% \mathrm{GF} \\
-\mathrm{M} 2\end{array}$ & 25 & 8.61 & 76.8 & 5.24 & 9.75 \\
\hline 3. & $\begin{array}{c}(7.5+7.5) \% \\
(\mathrm{SF}+\mathrm{MK}) \\
1.5 \% \mathrm{SP} \\
1.5 \% \mathrm{GF} \\
-\mathrm{M} 3\end{array}$ & 50 & 8.20 & 74.21 & $\mathrm{CO}$ & 8.68 \\
\hline 4. & $\begin{array}{c}(7.5+7.5) \% \\
(\mathrm{SF}+\mathrm{MK}) \\
1.5 \% \mathrm{SP} \\
1.5 \% \mathrm{GF} \\
-\mathrm{M} 4\end{array}$ & 75 & 7.96 & 68.69 & 4.87 & 8.43 \\
\hline 5. & $\begin{array}{c}(7.5+7.5) \% \\
(\mathrm{SF}+\mathrm{MK}) \\
1.5 \% \mathrm{SP} \\
1.5 \% \mathrm{GF} \\
-\mathrm{M} 5\end{array}$ & 100 & 7.45 & 65.12 & 4.62 & 7.98 \\
\hline
\end{tabular}




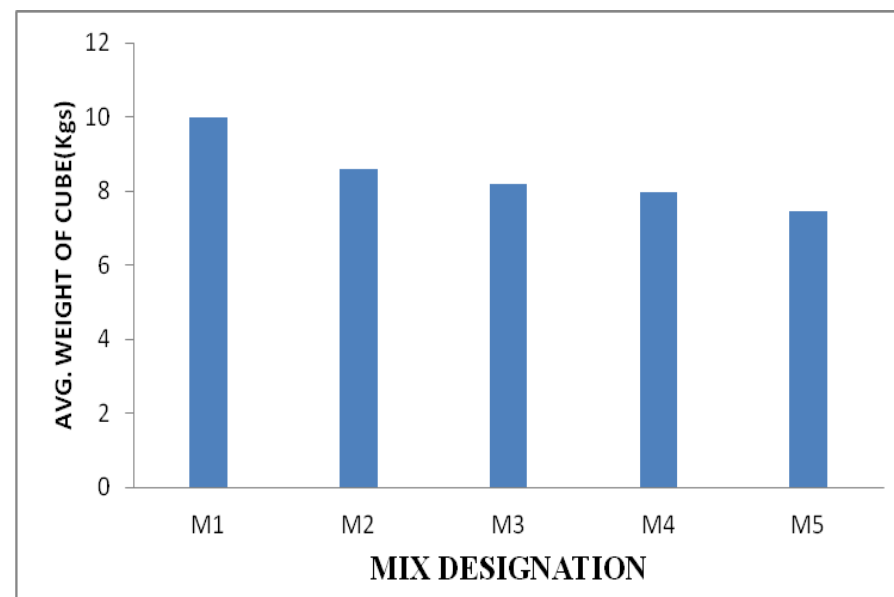

Fig.20 Avg. Weight of the Cube Specimens

From the above graph, it can be concluded that with the increase in percentage replacement of light weight aggregate i.e., pumice stone to natural aggregate, the avg. weight of cube specimens is found to be decreasing.

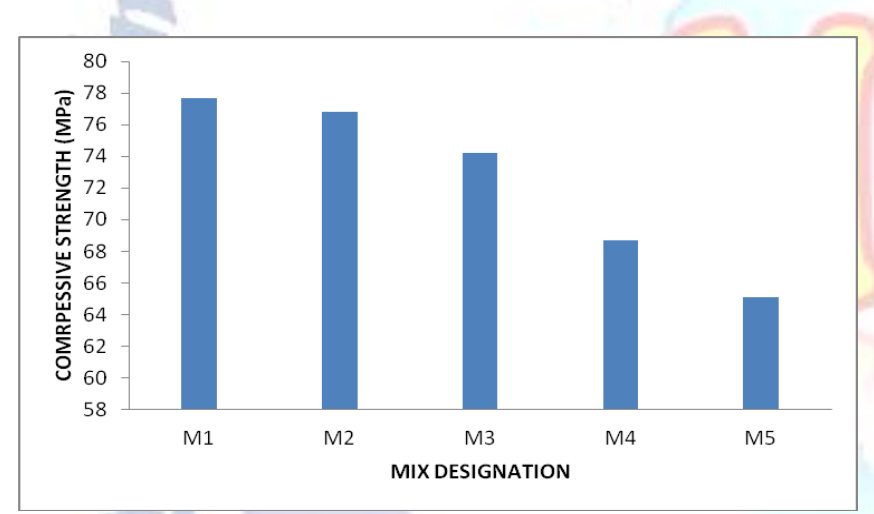

Fig. 21 Compressive strength of high strength glass fiber reinforced light weight concrete

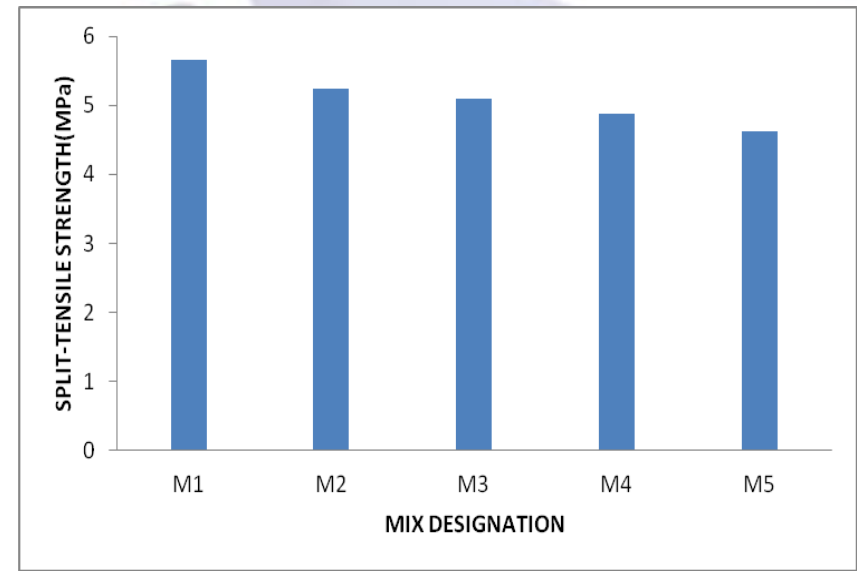

Fig.22 Split-tensile strength of high strength glass fiber reinforced light weight concrete

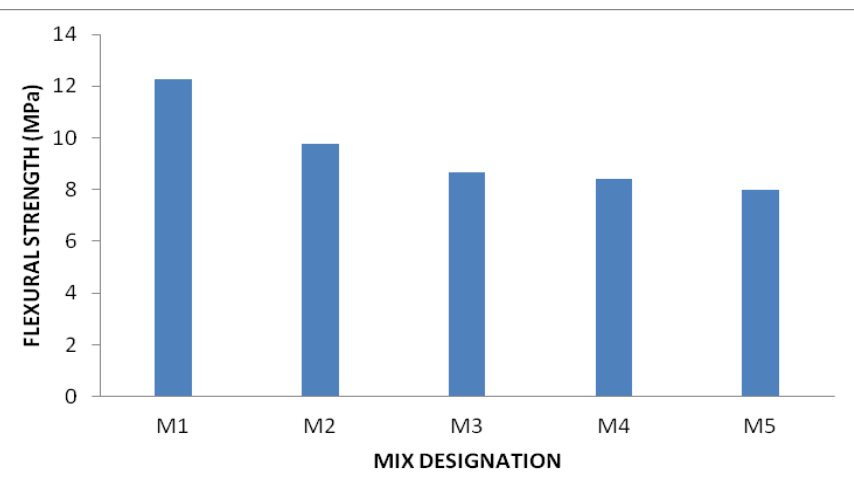

Fig.23 Split-tensile strength of high strength glass fiber reinforced light weight concrete

i.From Fig. 21,22 and 23, it can be concluded that with the increase in percentage replacement of coarse aggregate with pumice stone aggregate, the mechanical strength characteristics of high strength grade concrete were found to be decreasing, but the strength are in the appreciable ranges.

ii. The optimal replacement level of pumice stone aggregate to natural coarse aggregate can be concluded to be $50 \%$ when glass fibers are utilized.

\section{Photographs}

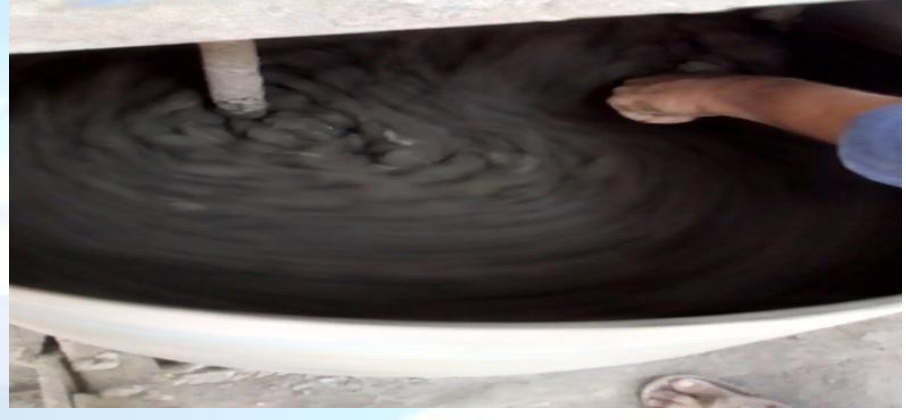

Fig. Mixing of Concrete in Mixer

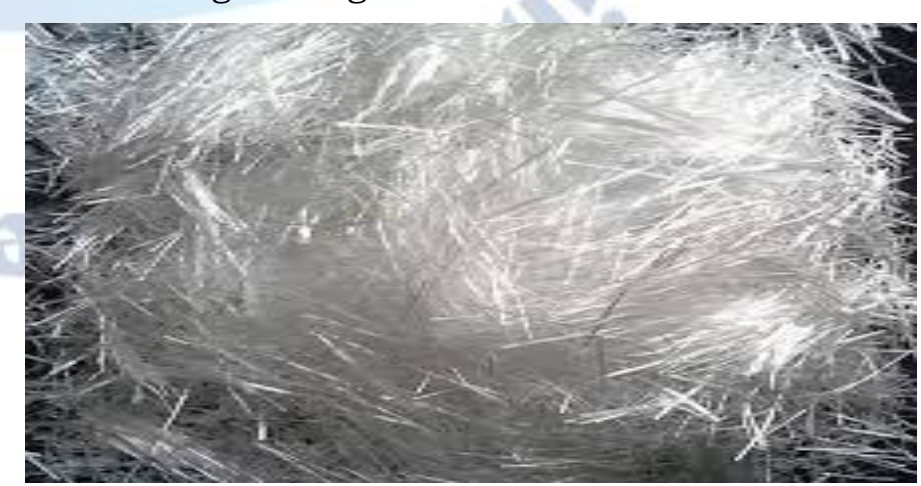

Fig.Glass fibers used in present study 


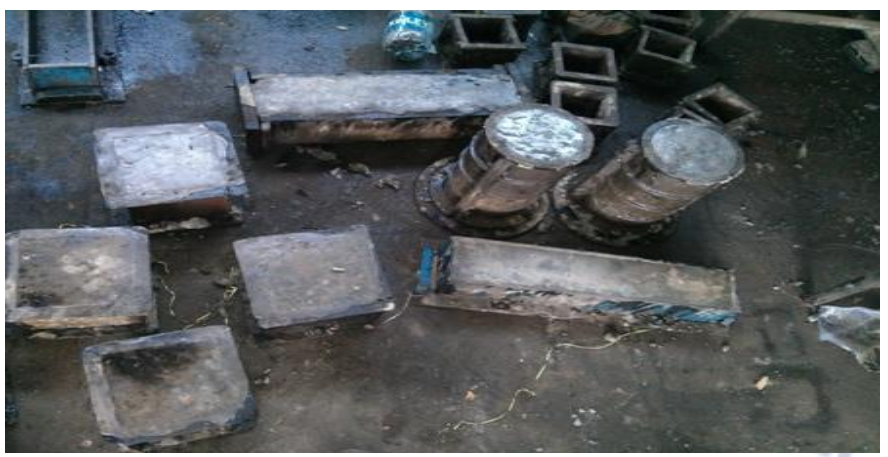

Fig. Cubes, Cylinders and Prisms after Concreting

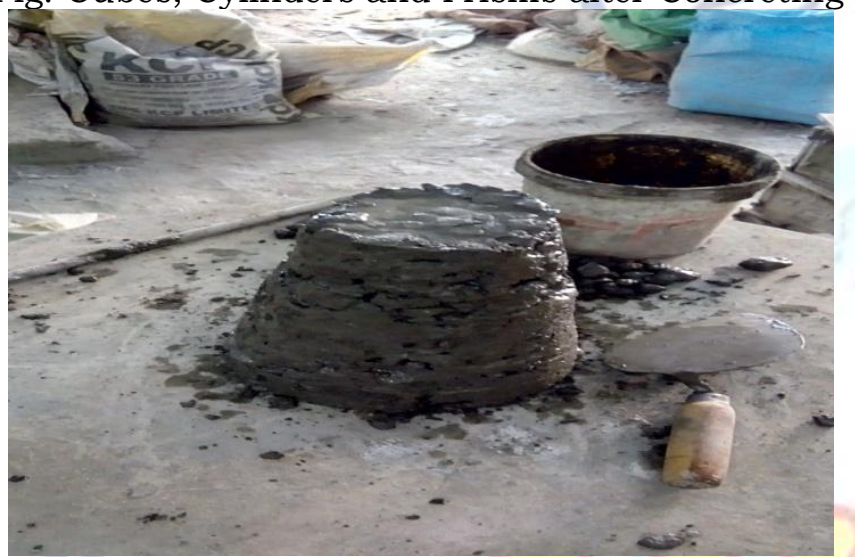

Fig. Slump Cone Test for Fresh Concrete Mix

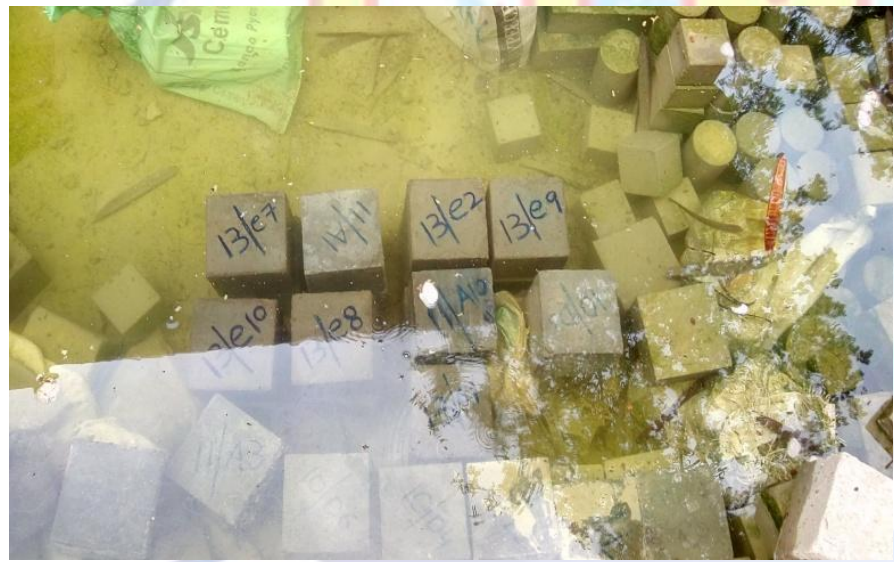

Fig. Concrete Specimens under water curing

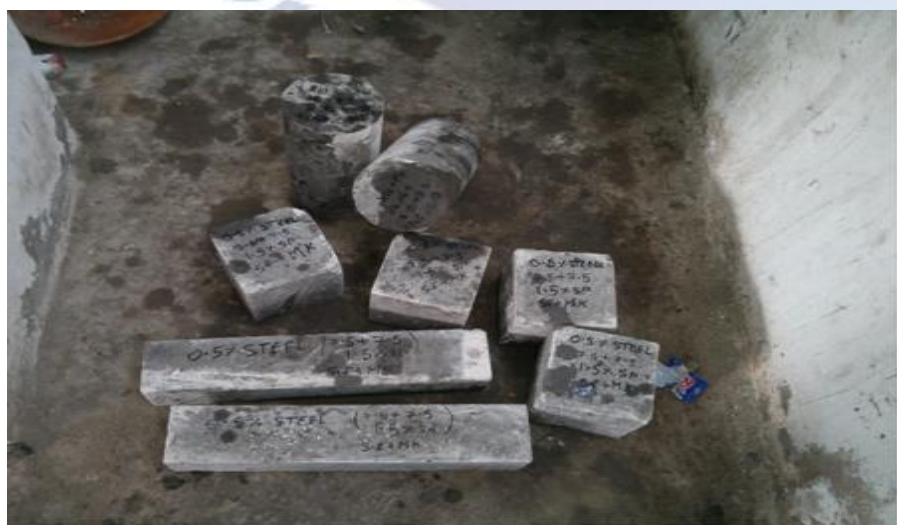

Fig. Specimens after water curing

\section{CONCLUSIONS:}

Depending on the experimental investigation conducted, the following conclusions were drawn

1. Inclusion of multi-mineral admixtures Metakaoline and Silica Fume apparently influenced the mechanical strength characteristics of HSC.

2. HSC prepared with $(7.5+7.5) \%(\mathrm{SF}+\mathrm{MK})$ with $1 \%$ SP showed superior properties in terms of compression, split-tension and flexural strengths when compared with the control mix and the percentage increase is found to be $8.3 \%, 2.40 \%$ and $0.61 \%$ respectively.

3. HSC prepared with $(7.5+7.5) \%(\mathrm{SF}+\mathrm{MK})$ with $1.5 \%$ SP showed superior properties in terms of compression, split-tension and flexural strengths when compared with the control mix and the percentage increase is found to be $10.6 \%, 5.79 \%$ and $10 \%$ respectively.

4. HSC prepared with $(7.5+7.5) \%(\mathrm{SF}+\mathrm{MK})$ with $1.5 \%$ SP and $1.5 \%$ glass fibers showed superior properties in terms of compression, split-tension and flexural strengths when compared with the control mix and the percentage increase is found to be $28.6 \%, 36.46 \%$ and $54.07 \%$ respectively. Further, 50\% replacement of natural aggregate with pumice stone is found to be appreciable in terms of mechanical strength characteristics of prepared concrete mix.

5. The inclusion of glass fibers in HSC mix has significantly enhanced the split-tensile as well as flexural strength of the high strength concrete along with compressive strength.

\section{REFERENCES}

[1] P.Muthupriya, K.Subramanian, B.G.Vishnuram, "Experimental Investigation on High Performance Reinforced Concrete Column with Silica Fume and Fly Ash as admixtures". Asian Journal of Civil Engineering, Vol.12 , No.5 (2011), Pages 597-618.

[2] B.B.Patil, P.D. Kumbhar "Strength and Durability Properties of high Performance Concrete incorporating High Reactivity Metakaolin", International Journal of Modern Engineering Research, Vol.2, issue.3,May-June 2012,pages 1099-1104.

[3] A.Ravichandran, K.Suguna and P.N.Raghunath "Strength Modeling of High-strength concrete with Hybrid Fiber Reinforcement". American Journal of Applied Sciences 6 (2):219-233, 2009.

[4] S. Eswari, P.N. Raghunath and K. Suguna," Ductility Performance of Hybrid Fibre Reinforced Concrete", American Journal of Applied Sciences 5 (9): 1257-1262, 2008, ISSN 1546-9239, 2008 Science Publications

[5] B.B.Patil, P.D. Kumbhar "Strength and Durability Properties of high Performance Concrete incorporating High Reactivity Metakaolin", International Journal of 
Modern Engineering Research, Vol.2, issue.3,May-June 2012,pages 1099-1104.

[6] A.Ravichandran, K.Suguna and P.N.Raghunath "Strength Modeling of High-strength concrete with Hybrid Fiber Reinforcement”. American Journal of Applied Sciences 6 (2):219-233, 2009.

[7] S. Eswari, P.N. Raghunath and K. Suguna," Ductility Performance of Hybrid Fibre Reinforced Concrete", American Journal of Applied Sciences 5 (9): 1257-1262, 2008, ISSN 1546-9239, 2008 Science Publications

[8] N. Sivalinga Rao, Y.Radha Ratna Kumari, V. Bhaskar Desai, B.L.P. Swami, "Fibre Reinforced Light Weight Aggregate (Natural Pumice Stone) Concrete", International Journal of Scientific \& Engineering Research Volume 4, Issue 5, May-2013 ISSN 2229-5518.

[9] S.Chandra and Berntsson, Light weight aggregate concrete: Science, technology and applications, Noyes Publications.

[10] Swamy R.N, Lambert G.H, "Mix Design and Properties of Concrete made from PFA, Coarse Aggregate and Sand", The International Journal of Cement Composite and Light Weight Concrete, Vol.5, No.4, 1983,PP 263-275.

[11] Taylor.P.C, "The Properties of High Strength Light Weight Concrete", Concrete 21(4), April 1987, pp 8-9.

[12] T. Parhizkar, M. Najimi and A.R. Pourkhorshidi, "Application of pumice aggregate in structural lightweight concrete", asian journal of civil engineering (building and housing) VOL. 13, NO. 1 (2012) PAGES 43-54.

[13] ACI Committee 318, Building Code Requirements for Reinforced Concrete (ACI 318-05) and Commentary, American Concrete Institute, Detroit, Mich, USA, 2005.

[14] Building Research Establishment, "Autoclaved aerated concrete," Building Research Establishment Digest 342, pp. 1-8, March 1989.

[15] A. S. Ezeldin and P. N. Balaguru, "Normal- and high-strength fiber-reinforced concrete under compression," Journal of Materials in Civil Engineering, vol. 4, no. 4, pp. 415-429, 1992.

[16] C. H. Henager, "Glass fibrous concrete-a review of testing procedures," in Proceedings of the Symposium on Fiber Concrete, pp. 16-28, London, UK, 1980.

[17] Dr.Salahldein Alsadey "Influence of Superplasticizer on Strength of Concrete", International Journal of Research in Engineering and Technology, Vol.1, No.3, 2012.

[18] M Suneel Et Al., "WORKABILITY AND STRENGTH CHARACTERISTICS OF M60 GRADE CONCRETE BY PARTIAL REPLACEMENT OF CEMENT WITH NANO Tio2", https://ukiericoncretecongress.com/Home/files/Proceedi ngs/pdf/UCC-2019-1036.pdf

[19] P. Bhargavi et al., "Experimental Analysis of Workability and Characteristic Strength of M40 and M60 Grade of Concrete by Partial Replacement of Cement with Nano TiO2", -International Journal for Innovative Research in Science \& Technology| Volume 6 | Issue 2 | July 2019 ISSN (online): 2349-6010.

[20] Gatadi Kiran Kumar, Ipsita Bose Roy Choudhury, V. Subbalakshmi, Alluri S Naveen Reddy, "Strength of M25 and M60 Grade Concrete with Used Foundry Sand", International Journal of Engineering and Advanced Technology (IJEAT) ISSN: 2249 - 8958, Volume-9 Issue-2, December, 2019

[21] Devananda Reddy et al., "Experimental Study on Mechanical Properties of High Strength Concrete for M60 Grade Concrete", International Journal of Science and Research (IJSR) ISSN (Online): 2319-7064.

[22] Rituraj.S. Rathore et al., "Partial Replacement of OPC by Silica Fume with M60 Grade Concrete", Journal of Civil Engineering and Environmental Technology p-ISSN:
2349-8404; e-ISSN: 2349-879X; Volume 3, Issue 8; July-September, 2016, pp. 684-689

[23] Prof. S .Vijaya Bhaskar Reddy, Pappi Reddy Mounika, "Strength and Durability Studies of Ternary Concrete", International Journal of Applied Engineering Research ISSN 0973-4562 Volume 13, Number 15 (2018) pp. 12161-12177

[24] Fayaz. Shaik et al., "Study on Strength Characteristics for M 60 Grade Concrete Using Fly Ash, Silica Fume, Metakaolin, and Glass Fibers", International Journal of Latest Technology in Engineering, Management \& Applied Science (IJLTEMAS) Volume V, Issue XI, November 2016 | ISSN 2278-2540.

[25] Salim Rawther, "Mechanical properties of concrete with pulverized used foundry sand asmineral admixture", International Journal of Civil Engineering and Technology (IJCIET), Volume 9, Issue 3, March 2018, pp. 158-169, Article ID: IJCIET_09_03_018

[26] Syed Afzal Basha et al., "Impact Of Using Stone Powder And Mineral Admixtures In High Strength Concrete", ijetms.in Issue:5, Volume No.4, September-2020 DOI: DOI: 10.46647/ijetms.2020.v04i05.015

[27] Suriya Mani et al., "Study on behaviour of GGBS as partial replacement of cement in concrete with addition of polycarboxylate ether", AIP Conference Proceedings > Volume 2240, Issue $1>10.1063 / 5.0011112$

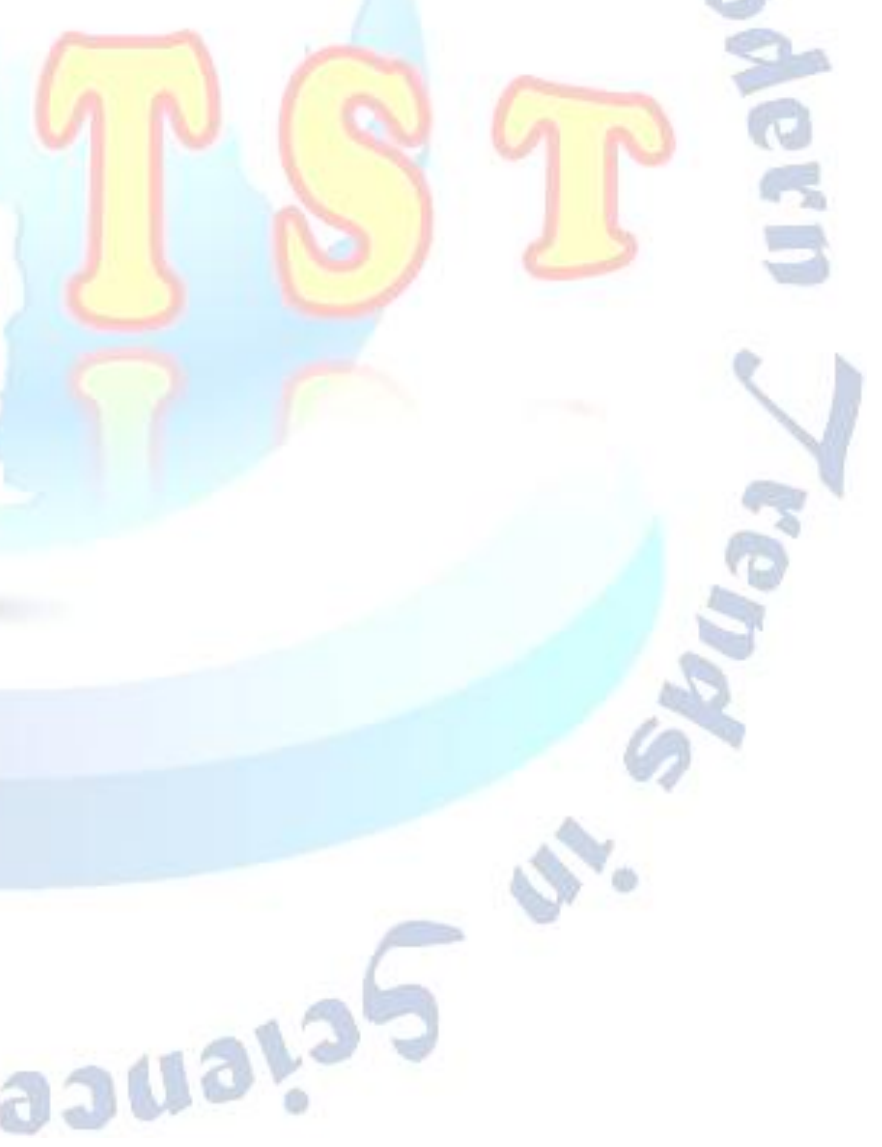

